\title{
Ichthyosis Prematurity Syndrome: A Case Report and Review of Known Mutations
}

ARTICLE in PEDIATRIC DERMATOLOGY · MAY 2014

Impact Factor: 1.02 · DOI: 10.1111/pde.12320

READS

21

5 AUTHORS, INCLUDING:

Judith Fischer

Universitätsklinikum Freiburg

86 PUBLICATIONS 3,563 CITATIONS

SEE PROFILE
Alan Irvine

Trinity College Dublin

204 PUBLICATIONS 8,465 CITATIONS

SEE PROFILE 


\title{
Ichthyosis prematurity syndrome: a case report and review of known mutations.
}

C.Kiely ${ }^{1}$, D. Devaney ${ }^{2}$, J Fischer ${ }^{3}$, P. Lenane ${ }^{1}$, A. D. Irvine ${ }^{4,5}$

Departments of 'Paediatric Dermatology and 2Pathology, Children's University Hospital Temple Street, ${ }^{3}$ Institute for Human Genetics, University Medical Center Freiburg, Freiburg, Germany

${ }^{4}$ Paediatric Dermatology, Our Lady's Children's Hospital, Crumlin

${ }^{5}$ Clinical Medicine, Trinity College Dublin

Correspondence to:

Alan D. Irvine MD FRCP FRCPI

Paediatric Dermatology,

Our Lady's Children's Hospital, Crumlin

Dublin 12, IRELAND

irvinea@tcd.ie

\section{Word count: 484}

\begin{abstract}
Ichthyosis prematurity syndrome (IPS; MIM 608649) is classified as a syndromic autosomal recessive ichthyosis (1). Here we describe two siblings with IPS and report a recurrent homozygous mutation: c.1430T>A which is predicted to lead to a $\mathrm{p}$.Val477Asp substitution in the FATP4 protein. This mutation has arisen for second time in an entirely distinct population from the Scandanavian population where this mutation was first described.
\end{abstract}

\section{CASE REPORT}

Patient 1, a male, whose parents were consanguineous, was born at 28 weeks gestation. A well demarcated, hyperkeratotic scale was noted over the scalp surrounded by an erythematous border. Similar hyperkeratotic scale was evident on the palms and soles (Fig. 1).

Immediately after birth he developed respiratory distress and required intubation. $\mathrm{He}$ remained intubated for six weeks. During this time he was noted to have a transient hypereosinophilia. The thickened keratoderma persisted over the scalp, palms and soles. The rest of his skin remained ichthyotic. Within two years of birth, the eruption had evolved into a mild flexural dermatitis with generalized ichthyosis.

Two years later a sibling of the index patient was born at 35 weeks gestation following spontaneous rupture of membranes. Significant polyhydramnios was noted. Skin findings were similar to her brother, with a well-demarcated hyperkeratotic scale over the scalp, hands and feet; the skin was mildly ichthyotic. At birth she had acute respiratory distress and attempts at resuscitation failed, resulting in her death. Autopsy revealed respiratory 
failure as the cause of death due to blocking of the airways by plugs formed from shed keratinocytes.

Histological examination of skin samples, from both siblings, showed a thickened epidermis with hyperkeratosis and a normal granular layer (Fig 2A). Electron microscopy demonstrated extensive lipid droplets in the stratum corneum and lipid vacuoles in the stratum granulosum (Figs 2B).

IPS was considered as a diagnosis and both siblings were tested for a mutation in FATP4. Sanger sequencing revealed a homozygous mutation: c.1430T $>$ A, which leads to a p.Val477Asp substitution. This mutation was not present in 100 normal populationmatched Caucasian alleles.

\section{DISCUSSION}

IPS is a very rare autosomal recessive disorder characterized by prematurity, respiratory distress and a thick caseous scale at birth. Affected individuals have lifelong 'ichthyosis' or stippled, thickened skin with frequent atopic manifestations.

Klar et al(2) recently described Mutations in the gene encoding the fatty acid transport protein 4 (FATP4, official gene name SLC27A4) causing IPS. The gene is located on the long arm of chromosome 9 (131,102,839-131.123, 749 GRCH37/hg19). Previously identified mutations are detailed in Table 1. FATP4 is a member of a family of integral transmembrane proteins important in the transport of exogenous fatty acids into cells.

There are four key features of IPS

1) Prematurity: Polyhydramnios in the second trimester of pregnancy leads to complications resulting in prematurity.

2) Skin abnormalities at birth: The epidermis is variably thickened, caseous, and desquamating either locally or generally.

3) Respiratory distress: Neonatal respiratory failure due to blocked airways can be fatal.

4) Eosinophilia. Perinatal eosinophilia has been reported.

Parents can be reassured of the indolent nature of the disease if the child survives the initial postpartum respiratory complications. The long-term prognosis is good; atopic dermatitis is the most common persisting feature. Genetic counseling should be advised for families. There is a $25 \%$ possible risk of IPS in future pregnancies. Prenatal testing is available, if the mutation is known, as in our case. 


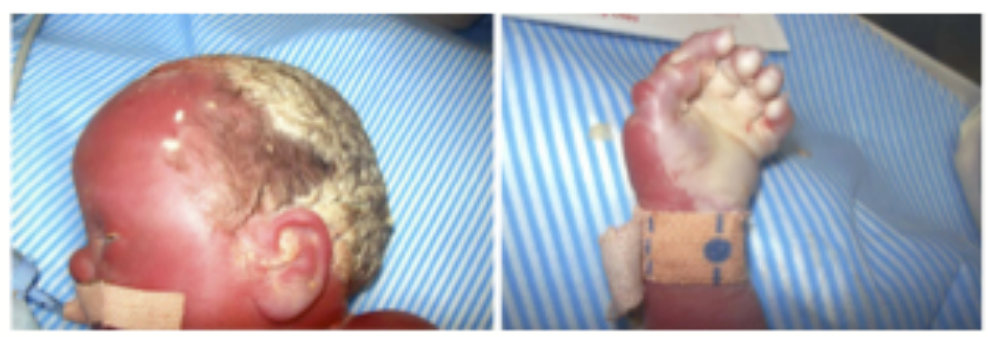

Figure 1. $(\mathrm{A}, \mathrm{B})$ Thick caseous scale over hands and scalp at birth.
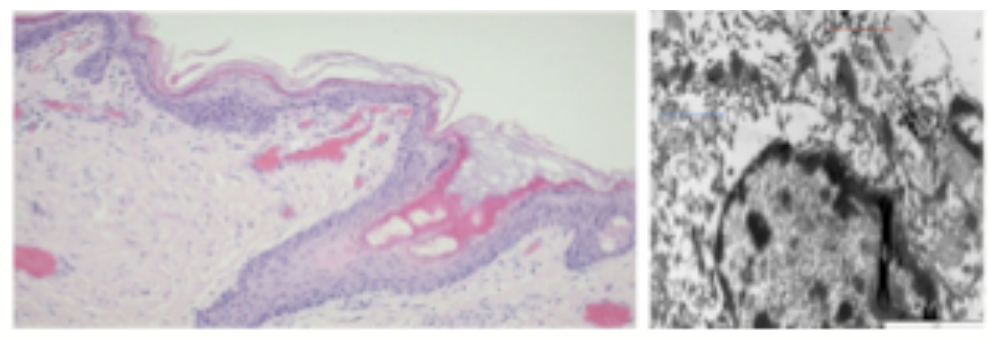

Figure 2. (A) Orthokeratotic hyperkeratosis which is non-bullous with an intact granular layer (Haematoxylin and eosin, original magnification). (B) Electron microscopy demonstrating increased lipid droplets (red arrow) in stratum corneum and lipid vacuoles (blue arrow) in stratum granulosum. 


\begin{tabular}{|c|c|c|c|c|c|c|}
\hline Mutation & Basepair & Location & Consequence & Protein domain & Population & Reference \\
\hline p.C168X ${ }^{2}$ & c. $504 \mathrm{c}>\mathrm{a}$ & Exon 3 & $\begin{array}{l}\text { Nonsense } \\
\text { mutation }\end{array}$ & & Scandinavia & Klar et al.(2) \\
\hline p.G35X $\mathrm{X}^{3}$ & c. $103 \mathrm{~g}>\mathrm{t}$ & Exon 2 & $\begin{array}{l}\text { Nonsense } \\
\text { mutation }\end{array}$ & $\begin{array}{l}\text { N-terminal } \\
\text { transmembrane } \\
\text { region }\end{array}$ & Scandinavia & $\begin{array}{l}\text { Sobol et al. } \\
\text { (3) }\end{array}$ \\
\hline Splice site & c. $716-1 \mathrm{~g}>\mathrm{a}^{2}$ & Exon 5 & $\begin{array}{l}\text { Splice site } \\
\text { mutation } \\
\text { predicting a } \\
\text { truncated protein }\end{array}$ & & N. Africa & Klar et al.(2) \\
\hline Splice site & c. $988-2 \mathrm{a}>\mathrm{g}^{2}$ & Exon 8 & $\begin{array}{l}\text { Splice site } \\
\text { mutation }\end{array}$ & & Scandinavia & Klar et al.(2) \\
\hline p.A92T ${ }^{2}$ & c. $274 \mathrm{~g}>\mathrm{a}$ & Exon 3 & $\begin{array}{l}\text { Missense } \\
\text { mutation }\end{array}$ & $\begin{array}{l}\text { ER localization } \\
\text { signal }\end{array}$ & Scandinavia & Klar et al.(2) \\
\hline p.S247P 2 & c. $739 t>c$ & Exon 5 & $\begin{array}{l}\text { Missense } \\
\text { mutation }\end{array}$ & $\begin{array}{l}\text { AMP-binding } \\
\text { domain }\end{array}$ & Scandinavia & Klar et al.(2) \\
\hline p.R374C 4 & c. $1120 \mathrm{c}>\mathrm{t}$ & Exon 8 & $\begin{array}{l}\text { Missense } \\
\text { mutation }\end{array}$ & $\begin{array}{l}\text { Highly conserved } \\
\text { domain }\end{array}$ & French & $\begin{array}{l}\text { Morice- } \\
\text { Picard F et } \\
\text { al.(4) }\end{array}$ \\
\hline p.R583H $\mathrm{H}^{2}$ & c. $1748 \mathrm{~g}>\mathrm{a}$ & Exon 12 & $\begin{array}{l}\text { Missense } \\
\text { mutation }\end{array}$ & C-terminal & Middle eastern & Klar et al.(2) \\
\hline p.Q300R ${ }^{2}$ & $\mathrm{c} .899 \mathrm{~g}>\mathrm{a}$ & Exon 7 & $\begin{array}{l}\text { Missense } \\
\text { mutation }\end{array}$ & $\begin{array}{l}\text { AMP-binding } \\
\text { domain }\end{array}$ & Scandinavian & Klar et al.(2) \\
\hline p.R504H ${ }^{3}$ & c. $1511 \mathrm{~g}>\mathrm{t}$ & Exon 11 & $\begin{array}{l}\text { Missense } \\
\text { mutation }\end{array}$ & $\begin{array}{l}\text { AMP-binding } \\
\text { domain }\end{array}$ & Scandinavia & $\begin{array}{l}\text { Sobol et al. } \\
\text { (3) }\end{array}$ \\
\hline p.V477D 3 & c. $1430 \mathrm{t}>\mathrm{a}$ & Exon 10 & $\begin{array}{l}\text { Missense } \\
\text { mutation }\end{array}$ & $\begin{array}{l}\text { AMP-binding } \\
\text { domain }\end{array}$ & Scandinavia & $\begin{array}{l}\text { Sobol et al. } \\
\text { (3) }\end{array}$ \\
\hline
\end{tabular}

\section{Table 1: Known FATP4/SLC27A4 Gene Mutations}




\section{References:}

1.Oji V, Tadini G, Akiyama M et al. Revised nomenclature and classification of inherited ichthyoses: results of the First Ichthyosis Consensus Conference in Sorèze 2009. J Am Acad Dermatol2010;63:607-41.

2. Klar J, Schweiger M, Zimmerman R et al. Mutations in the fatty acid transport protein 4 gene cause the ichthyosis prematurity syndrome. Am J Hum Genet. 2009; 85:248-253.

3. Sobol M, Dahl N, Klar J. FATP4 missense and nonsense mutations cause similar features in Ichthyosis Prematurity Syndrome. BMC Res Notes 2011;4:90.

4.Morice-Picard F, Leaute-Labreze C, Decor A et al. A novel mutation in the fatty acid transport protein 4 gene in a patient initially described as affected by self-healing congenital verruciform hyperkeratosis. Am J Med Genet. 2010;152:2664-2665. 